\title{
DETERMINING THE FACTORS AFFECTING REPRODUCTION OF AN ENDEMIC BLACK PINE VARIETY [PINUS NIGRA SUBSP. PALLASIANA VAR. YALTIRIKIANA] IN TURKEY
}

\author{
ORAL, D. \\ Istanbul University Cerrahpasa, Faculty of Forestry, Department of Forest Botany \\ 34473 Sariyer, Istanbul, Turkey \\ e-mail: dilek@istanbul.edu.tr; phone: +90-212-338-2400/25322; fax: +90-212-226-1113 \\ ORCID ID: 0000-0002-7627-5663
}

(Received $13^{\text {th }}$ Apr 2019; accepted $16^{\text {th }}$ Jul 2019)

\begin{abstract}
Pinus nigra subsp. pallasiana var. yaltirikiana has a very restricted spread, and is an endemic black pine variety in Turkey. This plant has a poor generative reproduction performance. It is unclear which factors are responsible for this low reproduction capacity. Therefore, objective of this study was to investigate pollen and seed characteristics of the plant. For this purpose, pollen samples were collected in the pollination period, and seed samples were collected in the cone ripening period in the natural distribution site of this plant in Black Sea Region. Pollen samples were examined whether or not they have normal shape and size. Seed samples were tested for germination percentage and seed size and soundness were also examined. Results showed that pollen samples seemed to have normal shape and size, and seeds have a germination percentage of 71 . This study indicated that the conservation of Pinus nigra subsp. pallasiana var. yaltirikiana through in-situ and ex-situ strategies and the establishment of a seed orchard in a different area by taking grafts are important in terms of ensuring continuity of limited number individuals.
\end{abstract}

Keywords: Pinus nigra subsp. pallasiana, yaltirikiana, germination, seed, pollen

\section{Introduction}

Pinus nigra J.F.Arnold subsp. pallasiana (Lamb.) Holmboe, which spreads across Balkans, Southern Carpathians, Crimea, Cyprus and Syria, constitutes forests in mountainsides of Black Sea, Marmara, Aegean and Central Anatolia regions and Toros Mountains of Turkey, and rarely seen at sea level (Coode and Cullen, 1965; Akkemik et al., 2011; Kandemir and Matarac1, 2018). In accordance with the recent studies, it is accepted that there are three varieties including var. fastigiata Businský, var. yaltirikiana Alptekin and var. pallasiana (f. pallasiana and f. seneriana (Saatcioglu) Kandemir \& Mataraci) in Turkey, and that its taxa except pallasiana f. pallasiana are endemic (Kandemir and Matarac1, 2018).

Pinus nigra J.F.Arnold subsp. pallasiana (Lamb.) Holmboe var. yaltirikiana Alptekin is distinguishable from other varieties by the fact that its cones are bigger (at least $8 \mathrm{~cm}$ ) and leaves are longer (at least $14 \mathrm{~cm}$ ) (Alptekin, 1987; Yaltırık, 1988; Kandemir and Matarac1, 2018; Oral and Mataraci, 2018). Alptekin (1987), who named the variety, indicated the cone sizes of Pinus nigra subsp. pallasiana var. yaltirikiana as $7.8 \mathrm{~cm}(\max .11 .19) \times 3.71 \mathrm{~cm}(\max .4 .4)$.

In Oral and Mataraci (2018)'s article, in which they identified a new epitype (ISTO 37320) instead of a holotype composed of only a cone, the average female cone size was $9.16(7.69-10.23) \times 3.94(3.55-4.31) \mathrm{cm}$, male cone size was $1.58(1.28-2.16) \mathrm{x}$ $0.54(0.48-0.62) \mathrm{cm}$; leave size was $17.21(13.80-20.20) \times 0.18(0.16-0.22) \mathrm{cm}$ and sheath length was $0.95(0.67-1.16) \mathrm{cm}$. In addition, it was especially emphasized that the cone and leaf length should be evaluated concomitantly for the diagnosis of taxon. 
It was known that this variety was in 1985 in Karabuk-Yenice and Sinop-Boyabat (Alptekin, 1987). Oral and Matarac1 (2018), during a field visit to these locations in 2017, stated that they survived owing to the fact that its individuals in Boyabat were taken under preservation. It is suggested by them that its danger catagory due to fewness of both individuals and seeds was "Critically endangered" (CR) (Ekim et al., 2000). During the field visit to Yenice, it never seen Pinus nigra subsp. pallasiana var. yaltirikiana even though all locations given in herbarium records were visited. There were black pines with shorter cones $(5.66-8.50 \mathrm{~cm})$ in these locations.

Yaman and Saribas (1999) compared pollen sizes of Pinus nigra subsp. pallasiana var. yaltirikiana in Karabuk-Yenice, which is its holotype location, with pollens of the other endemic black pines, which were taken from natural areas. As a result of the study, it was stated that it should be compared with the pollen samples in SinopBoyabat due to the fact that frequency distribution of Pinus nigra subsp. pallasiana var. yaltirikiana's pollen sizes (length-L and width-l) was not normal.

In this study, it is aimed at determining vitality of the seeds of Pinus nigra subsp. pallasiana var. yaltirikiana in order to ensure the sustainability of the existence of its in Sinop-Boyabat. Therefore, it has been investigated number of sound seeds and germination percentage, and the morphological characteristics of its pollen to determine whether it has especially a morphological development inhibitive to fertilization.

\section{Materials and methods}

Pollen and seed samples were collected from the trees growing only in Sinop-Boyabat, Karageriş Mountain, $\left(41^{\circ} 18^{\prime} 49,91^{\prime \prime} \mathrm{K}, 34^{\circ} 34^{\prime} 41,15^{\prime \prime} \mathrm{D}\right)$ at elevation of $1239 \mathrm{~m}$ (Figs.1 and 2).

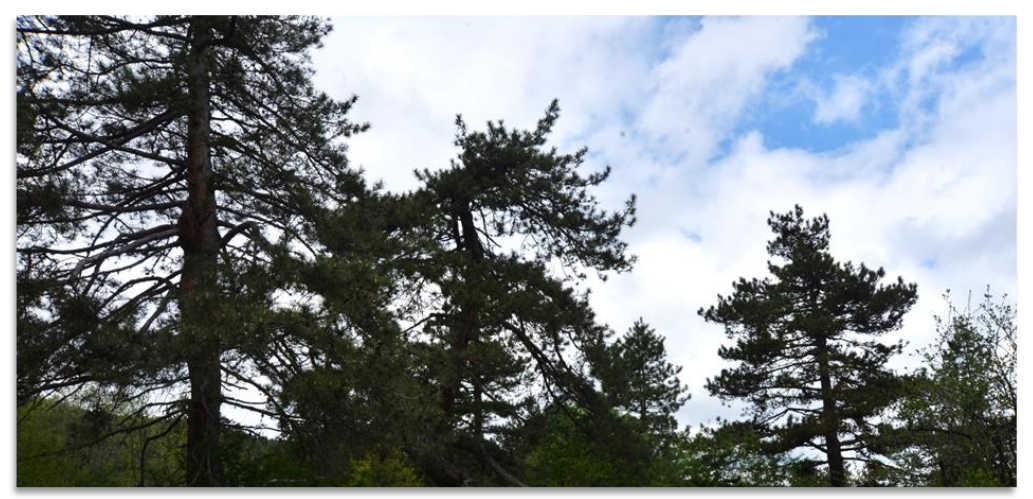

Figure 1. Individuals of Pinus nigra subsp. pallasiana var. yaltirikiana in BoyabatKapaklipinar

Only four trees were present in the site with ages of approximately between 80-100 years and height of 10-12 m. Dominant vegetation in the site includes some tree species such as Pinus nigra J.F.Arnold subsp. pallasiana (Lamb.) Holmboe var. pallasiana, Pinus sylvestris L. var. hamata Steven f. hamata, Juniperus communis L. subsp. saxatilis Pall. in the overstorey cover, some schrub species such as Cistus laurifolius L., Rubus canescens DC. var. canescens, Rosa canina L., Crataegus monogyna Jacq. subsp. monogyna, Mespilus germanica L. and some herbaceous plants such as Veronica chamaedrys L, Dactylis glomerata L., Poa апnua L. in the understorey cover. 
Mean annual precipitation is about $620 \mathrm{~mm}$ and most of it falls between September and June. The driest month is July, with $30 \mathrm{~mm}$ of rainfall. Most of the precipitation here falls in December, averaging $75 \mathrm{~mm}$. Average annual temperature is around $12.9^{\circ} \mathrm{C}$ and changes between $4^{\circ} \mathrm{C}$ in January and $21.7^{\circ} \mathrm{C}$ in July (Climate-Data.org, 2019). The site has a deep soil $(>80 \mathrm{~cm})$ with sandy loam texture covered with mull type forest floor with $2 \mathrm{~cm}$ depth (GDF, 2011).

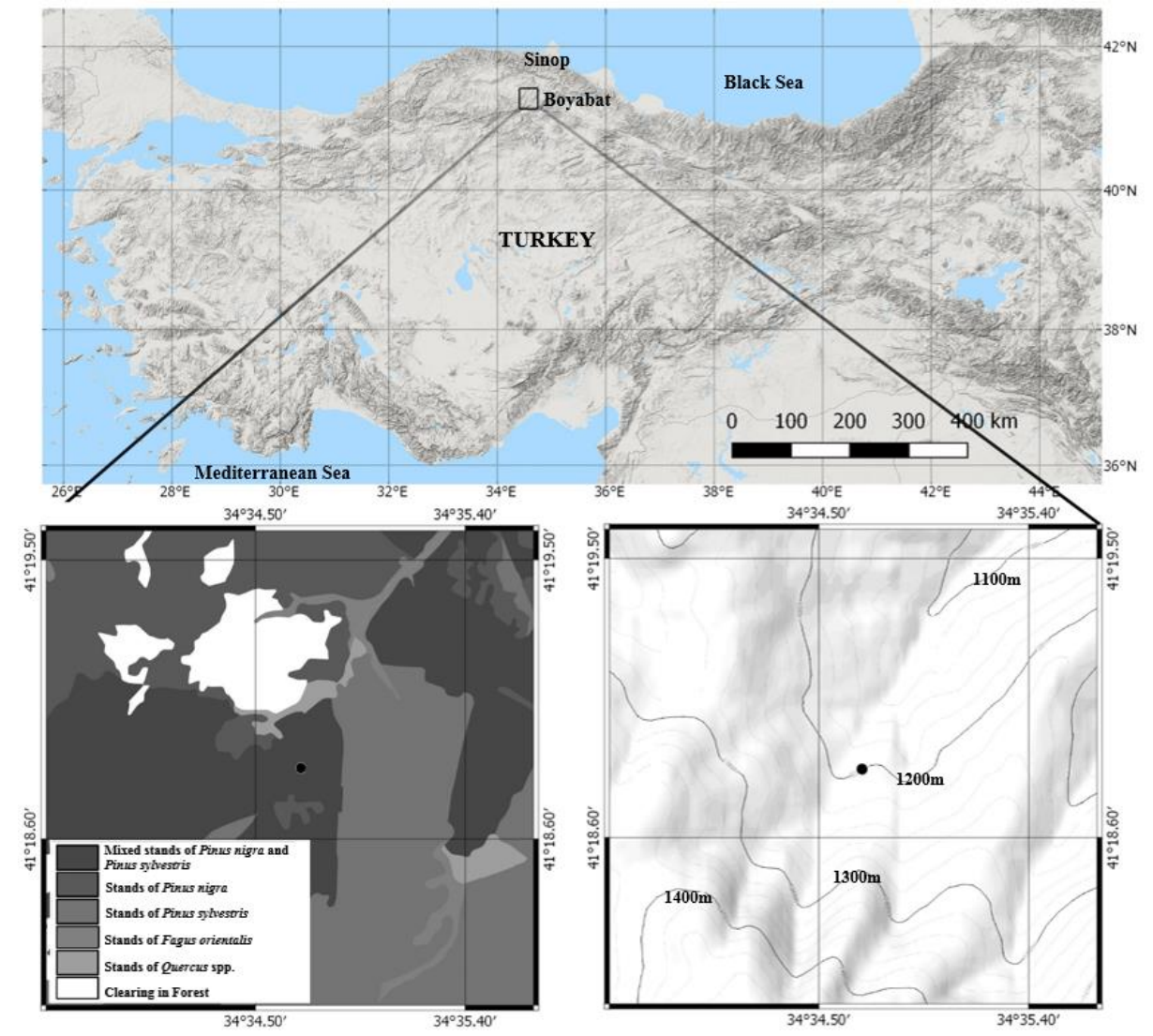

Figure 2. The location of the sample collection area (•) and the different types of habitats in its surrounding

Pollen samples were taken from each of four trees at the height of $3 \mathrm{~m}$ above soil surface in the pollination period in May 2018 and brought to Palynology Laboratory of Forest Botany Department at Istanbul University Cerrahpasa (I.U.C.) Faculty of Forestry. Then, pollen samples preparations were prepared separately for each individual tree according to the Wodehouse method (Wodehouse, 1959) and the measurements were carried out after waiting for 2 months for pollens in preparations to reach a normal form and sizes (Aytug, 1960). Then, they were examined. The measurements of pollen grains sizes in the preparations were done in the Leica DM750 light microscope (LM) as computer assisted, and 10x ocular, x40, x100 immersion objective were used. Under the light microscope, on equatorial axis of the pollen samples, length $(\beta)$ and height $(\mathrm{P})$ of saccus, distance from pollen to the outermost end of the saccus (p), height (h) of pollen body; on polar axis of theirs, length (L) and width (l) of pollen, length (B) and width (b) of saccus, distance from pollen to the outermost end of the saccus (be) were measured (Fig. 3) (Aytug, 1967). 
At least 50 measurements were performed for each pollen feature in each of the 4 preparations, then the averages were taken. A part of these pollens was kept in the fridge in $+4^{\circ} \mathrm{C}$ to examine with Scanning Electron Microscope (SEM). The size of the pollen, and ornamentation were studied by taking photos with both SEM and LM.

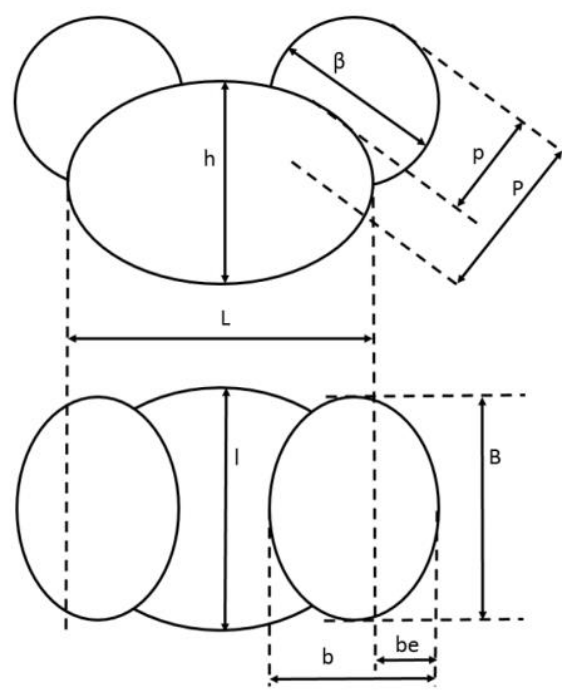

Figure 3. Pine pollen sizes (upper: polar axis, $\beta$ : length of saccus, $P$ : height of saccus, $p$ : distance from pollen to the outermost end of the saccus, h: height of pollen body; lower: equatorial axis, L: length of pollen, l: width of pollen, B: length of saccus, $b$ : width of saccus, be: distance from pollen to the outermost end of the saccus)

On December 20, 2018, cone samples were collected in order to determine the viability of the seeds in 2 years old cones of Pinus nigra subsp. pallasiana var. yaltirikiana. A total of 17 cones from four trees were collected from any side of canopy cover at the height of 3-6 m above soil surface. In order not to affect sustainability of its presence in the location, the number of cones was limited by also taking into account the fact that it already has a small number of individuals. The cones, which were brought to I.U.C. Faculty of Forestry, Department of Silviculture, Seed Technology and Silviculture Laboratory, were kept in drying-oven at a temperature of $46^{\circ} \mathrm{C}$ for 24 hours so that seeds could be taken out (Genc, 2004). Only seeds in 13 cones were counted as there were no seeds in 4 cones; seed length, width and thickness, and wing length and width were measured; and the seeds were weighed to determine their weights.

406 seeds were divided into four groups and placed on filter paper saturated with deionized water in 4 petri dishes at $20^{\circ} \mathrm{C}\left( \pm 0.5^{\circ} \mathrm{C}\right)$ for germination test. The seeds were considered to be germinated when radicles showed geotropism. Seed germinations were monitored for 28 days. As the seeds germinated they removed from the petri dishes. Ungerminated seeds were checked with cutting test for soundness. Germinated seeds were planted into pots (Boydak and Çalışkan, 2014). Besides, it was ensured that they continued development in order to determine the number of cotyledon. The seeds germinated within first week of the study. Planted into pots in the nursery and monitored for seedling survival for 60 days.

In order to determine whether or not a change exists in chromosome number, mitotic chromosomes were prepared from root tips and pre-treated with $\alpha$-bromo-naphthalene $(\mathrm{ABN})$ at $+4^{\circ} \mathrm{C}$ for $24 \mathrm{~h}$. Roots were fixed for a minimum of $2 \mathrm{~h}$ in absolute ethanol: 
glacial acetic acid, $(3: 1, \mathrm{v} / \mathrm{v})$, hydrolysed at $60^{\circ} \mathrm{C}$ in $1 \mathrm{~N} \mathrm{HCl}$ for $16 \mathrm{~min}$ and stained in Feulgen reagent. Finally, root tips were squashed in $1 \%$ aceto-orcein. Chromosomes were counted in the groups of in the preparation prepared from the crushed root tips (Altınordu et al., 2014).

Main statistical parameters were estimated and presented in the result section (Akalp, 2016).

\section{Results and Discussion}

The results of measurements made for pollen sizes are given in Table 1 by comparison with the results of literature studies. According to the results of observations and measurements made in pollen preparations showed that pollens of Pinus nigra subsp. pallasiana var. yaltirikiana were not defective and that there was no obstacle for seed formation by fertilization.

Table 1. Mean $(\bar{x} \pm S D)$ measurements of pollen dimensions of Pinus nigra subsp. pallasiana varieties

\begin{tabular}{|c|c|c|c|c|c|c|}
\hline \multirow{2}{*}{\multicolumn{2}{|c|}{$\begin{array}{l}\text { Measured parts } \\
(\mu \mathrm{m})\end{array}$}} & \multirow{3}{*}{\begin{tabular}{|c|} 
Present study \\
$\begin{array}{l}\text { var. yaltirikiana } \\
\text { (Boyabat-Sinop) }\end{array}$ \\
\end{tabular}} & \multicolumn{4}{|c|}{ Results of previous (literature) studies } \\
\hline & & & \multirow{2}{*}{\begin{tabular}{|c|}
$\begin{array}{l}\text { var. yaltirikiana } * \\
\text { (Yenice-Karabük) }\end{array}$ \\
$46.78 \pm 6.79 * * *$ \\
\end{tabular}} & \multirow{2}{*}{\begin{tabular}{|c|}
$\begin{array}{c}\text { var. fastigiata } \\
\text { (Kütahya) }\end{array}$ \\
$51.97 \pm 8.44 * * *$ \\
\end{tabular}} & \multirow{2}{*}{$\begin{array}{l}\begin{array}{l}\text { var. pallasiana } \\
\text { f. şeneriana } \\
\text { (Bolu) }\end{array} \\
55.13 \pm 3,68^{* * *}\end{array}$} & \multirow{2}{*}{$\begin{array}{c}\begin{array}{c}\text { var. pallasiana } \\
\text { f. pallasiana } \\
\text { (Muğla) }\end{array} \\
57.04 \pm 4.21 * * *\end{array}$} \\
\hline \multirow{5}{*}{ Polar view } & $\mathbf{L}$ & & & & & \\
\hline & 1 & $37.32 \pm 3.62$ & $43.57 \pm 5.86$ & $46.20 \pm 6.53$ & $47.03 \pm 3.63$ & $44.96 \pm 3.12$ \\
\hline & B & $35.18 \pm 2.09$ & $38.37 \pm 3.60$ & $39.45 \pm 5.19$ & $41.17 \pm 2.23$ & $39.80 \pm 3.01$ \\
\hline & b & $26.95 \pm 1.84$ & $28.96 \pm 3.71$ & $29.11 \pm 3.42$ & $30.41 \pm 2.23$ & $30.20 \pm 2.38$ \\
\hline & be & $10.23 \pm 1.61$ & $10.73 \pm 2.68$ & $10.97 \pm 2.45$ & $11.28 \pm 2.27$ & $10.28 \pm 2.28$ \\
\hline \multirow{4}{*}{$\begin{array}{l}\text { Equatorial } \\
\text { view }\end{array}$} & $\mathbf{h}$ & $32.27 \pm 2.32$ & $37.38 \pm 3.91$ & $40.04 \pm 5.41$ & $41.65 \pm 2.90$ & $39.84 \pm 3.32$ \\
\hline & $\boldsymbol{\beta}$ & $29.46 \pm 1.68$ & $32.74 \pm 2.32$ & $32.39 \pm 5.21$ & $33.56 \pm 2.83$ & $31.48 \pm 3.21$ \\
\hline & $\mathbf{P}$ & $24.36 \pm 1.36$ & $28.15 \pm 2.78$ & $27.54 \pm 4.19$ & $28.22 \pm 3.42$ & $25.76 \pm 2.19$ \\
\hline & $\mathbf{p}$ & $16.31 \pm 1.26$ & $14.21 \pm 3.59$ & $15.80 \pm 2.75$ & $15.03 \pm 1.82$ & $17.20 \pm 2.04$ \\
\hline \multirow{6}{*}{ Ratios } & $\mathrm{L} / \mathrm{l}$ & 1.25 & 1.07 & 1.12 & 1.17 & 1.27 \\
\hline & $\mathbf{L} / \mathbf{h}$ & 1.45 & 1.25 & 1.30 & 1.32 & 1.43 \\
\hline & $\mathbf{B} / \mathbf{b}$ & 1.31 & 1.32 & 1.36 & 1.35 & 1.32 \\
\hline & be/b & 0.38 & 0.37 & 0.38 & 0.37 & 0.34 \\
\hline & $\boldsymbol{\beta} / \mathbf{P}$ & 1.21 & 1.16 & 1.18 & 1.19 & 1.22 \\
\hline & $\mathbf{p} / \mathbf{P}$ & 0.67 & 0.50 & 0.57 & 0.53 & 0.67 \\
\hline
\end{tabular}

* Yaman and Sarıbaş (1999), ** Aytuğ (1967), ***SD (standard deviation)

Figure 4 shows polar and equatorial view of Pinus nigra subsp. pallasiana var. yaltirikiana pollens under LM and their exine surfaces under SEM. As in the other varieties (Yaman and Saribas, 1999), bisaccate pollens are inaperture; recesses and protrusions are apparent; pollen ornamentation is verrucate, and its structure is tectatae; saccus ornamentation is regular; it consists of small closed islets and canals (Fig. 4).

It is seen that sizes of pollens of all varieties of Pinus nigra subsp. pallasiana (Table 1) were similar; however, pollens of Pinus nigra subsp. pallasiana var. yaltirikiana, which were collected from both locations, were smaller than the pollens of other varieties. When Pinus nigra subsp. pallasiana var. yaltirikiana pollens of two locations (Boyabat and Yenice) were compared, it was found that the width (1), height $(h)$ and saccus sizes $(\beta, P, B, b, b e)$ of pollens in Sinop were lower, while distance from pollen to the outermost end of the saccus (p) was higher. In contrast to pollens of 
Yenice (Yaman and Sarıbas, 1999), the frequency distributions of pollen dimensions of samples collected from Boyabat were normal. When $\mathrm{L} / \mathrm{l}$ and $\mathrm{L} / \mathrm{h}$ ratios were compared, it can be said that pollens in Boyabat is slightly flattened in equatorial view.

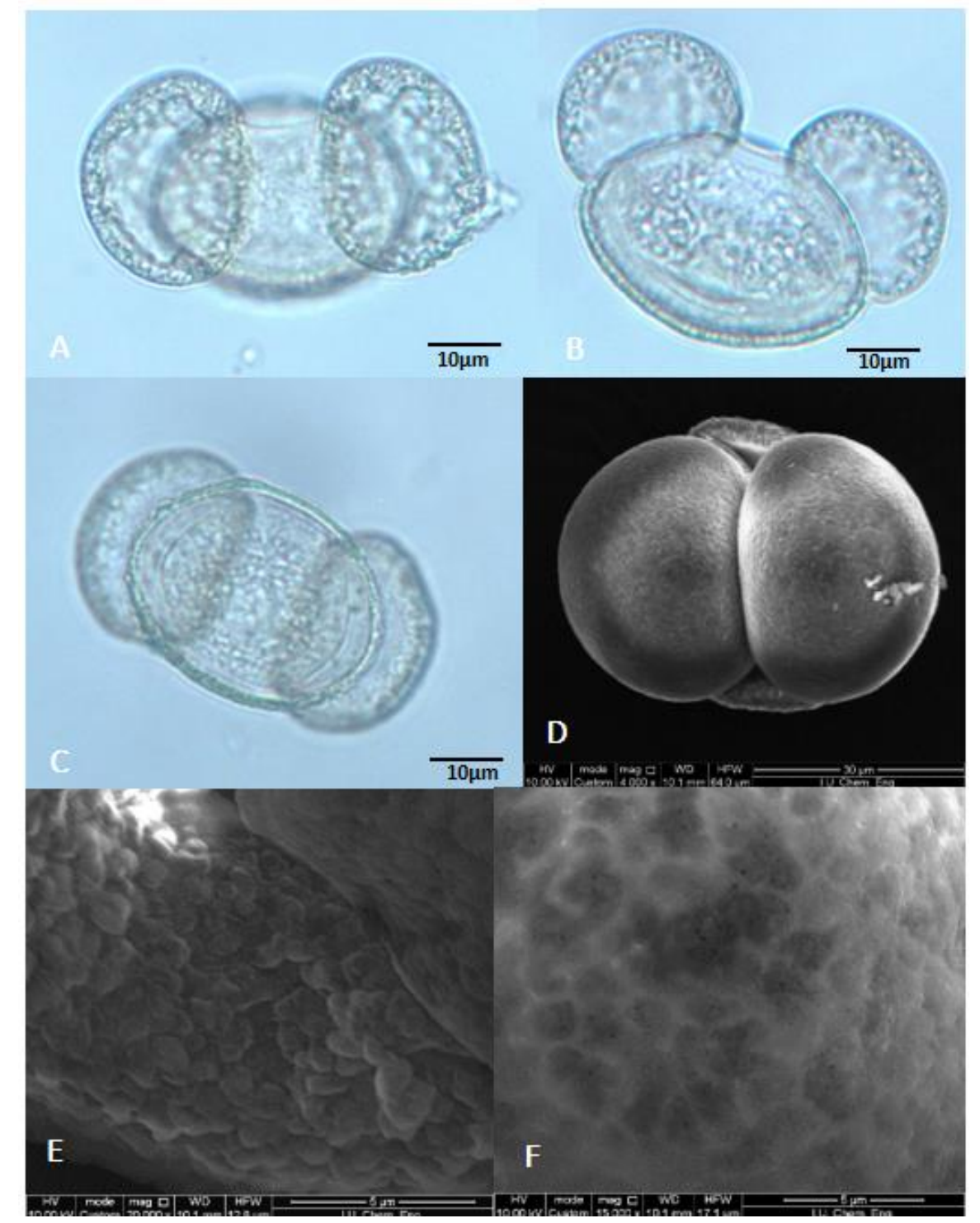

Figure 4. Pollens of Pinus nigra subsp. pallasiana var. yaltirikiana. A-C (Light microscopeLM): A-Polar (Distal), B-Equatorial, C-Polar (Proximal) views; D-F (SEM): D-Dry pollen grain, E-Exine surface (proximal pole), F-Exine surface (saccus)

It is shown that results of the measurements made on 406 seeds and 234 seed wings of Pinus nigra subsp. pallasiana var. yaltirikiana in Table 2. The number of seeds in the first three cones were very low. The sizes of the seeds were $7.10 \times 3.83 \times 2.40 \mathrm{~mm}$; while the seed-wing sizes were $34.88 \times 8.26 \mathrm{~mm}$. In literature, the seed sizes of Pinus nigra subsp. pallasiana was given as 6.5 (4-9) x $3.71(3-4) \mathrm{mm}$; the wing sizes of it as 24.73 x $7.7 \mathrm{~mm}$ (Alptekin, 1987; Kandemir and Mataracı, 2018). Accordingly, wing of Pinus nigra subsp. pallasiana var. yaltirikiana seed is longer. 
Atay (1959) stated that average germination capability of black pine seeds was $91.3 \%$, average germination energy was $62 \%$, and 1000 seed weight was $22.5 \mathrm{~g}$. As compared to results of previous studies about seeds of Pinus nigra subsp. pallasiana var. yaltirikiana, mean germination percentage was $71 \%$ on $28^{\text {th }}$ day and the average germination energy was 47\%, and 1000 seed weight was around $21.14 \mathrm{~g}$ (Table 3). Although the germination percentage is considered as the percentage of seeds germinated within the first 7 days, the values at days 4, 7 and 10 can also be used in some cases that require precision (Boydak and Çalışkan, 2014).

Table 2. Some characteristics of the seeds of Pinus nigra subsp. pallasiana var. yaltirikiana

\begin{tabular}{|c|c|c|c|c|c|c|c|}
\hline & \multirow{2}{*}{$\begin{array}{c}\text { Number of } \\
\text { sound seed in } \\
\text { a cone }\end{array}$} & \multirow{2}{*}{$\begin{array}{l}1000 \text { seed } \\
\text { weight }(g)\end{array}$} & \multicolumn{3}{|c|}{ Seed $(n=406)$} & \multicolumn{2}{|c|}{ Seed wing $(n=234)$} \\
\hline & & & $\begin{array}{c}\text { Length } \\
(\mathbf{m m})\end{array}$ & $\begin{array}{l}\text { Width } \\
(\mathbf{m m})\end{array}$ & $\begin{array}{c}\text { Thickness } \\
\text { (mm) }\end{array}$ & $\underset{(n=406)}{\text { Seed }}$ & $\begin{array}{l}\text { Width } \\
(\mathbf{m m})\end{array}$ \\
\hline $\begin{array}{l}\text { Mean } \\
\text { Range }\end{array}$ & $\begin{array}{c}18 \\
0-35\end{array}$ & $\begin{array}{c}21.14 \\
11.4-35.1\end{array}$ & $\begin{array}{c}7.10 \\
4.15-8.69\end{array}$ & $\begin{array}{c}3.83 \\
2.59-4.79\end{array}$ & $\begin{array}{c}2.40 \\
0.96-3.42\end{array}$ & $\begin{array}{c}34.88 \\
25.79-41.07\end{array}$ & $\begin{array}{c}8.26 \\
5.29-10.42\end{array}$ \\
\hline
\end{tabular}

Table 3. Percentages of sound seed, germination, germination rates and number of cotyledon for each cone samples of Pinus nigra subsp. pallasiana var. yaltirikiana

\begin{tabular}{c|c|c|c|c|c|c|c|c|c|c}
\hline & \multirow{2}{*}{ All seeds } & \multirow{2}{*}{$\begin{array}{c}\text { Sound } \\
\text { seeds }\end{array}$} & \multirow{2}{*}{$\begin{array}{c}\text { Empty } \\
\text { seeds }\end{array}$} & \begin{tabular}{c} 
Germination \\
seeds (for all \\
\cline { 5 - 10 }
\end{tabular} & & & \multicolumn{5}{|c|}{ Geeds) } & $\mathbf{4}$ & $\mathbf{7}$ & $\mathbf{1 0}$ & $\mathbf{1 4}$ & $\mathbf{2 8}$ & Cotyledon \\
\hline Number & 406 & 198 & 208 & 140 & 70 & 93 & 109 & 126 & 140 & $8.3(6-10)$ \\
$\boldsymbol{\%}$ & - & 49 & 51 & 35 & 35 & 47 & 55 & 63 & 71 & - \\
\hline
\end{tabular}

As seen from Table 3, almost half of the seeds were sound with a germination percentage of 71 (Fig. 5).

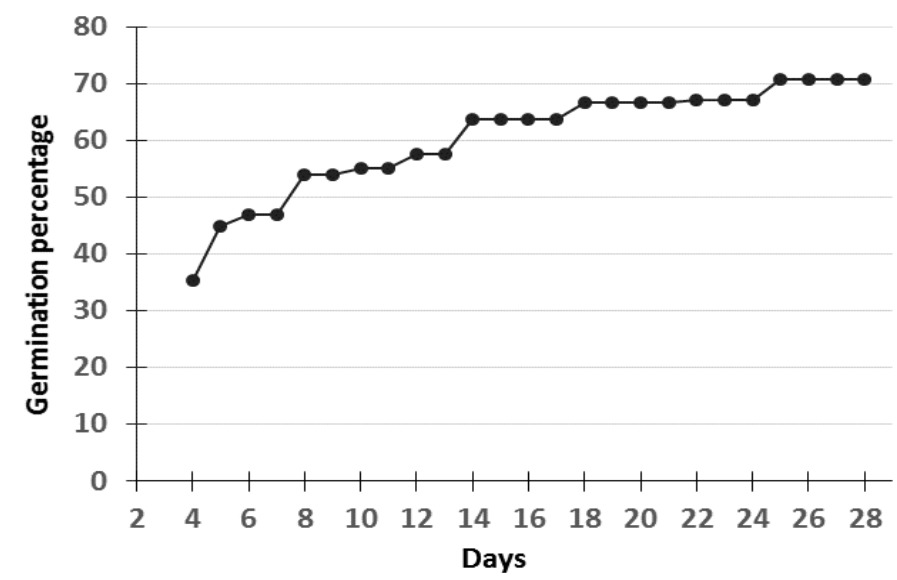

Figure 5. Germination of Pinus nigra subsp. pallasiana var. yaltirikiana seeds under $20^{\circ} \mathrm{C}$

As compared to results of previous studies sound seed production and germination of Pinus nigra subsp. pallasiana var. yaltirikiana was lower when sound seeds were considered. Moreover, if all seeds including unsound ones were considered, germination percentage dropped to $35 \%$, and $49.3 \%$ of the germination took place in the four-day period in germination chamber. 
140 seeds were germinated under laboratory conditions, and germinated seeds were planted into pots. 93 out of 140 germinated seeds were planted into pots seven days after the germination and monitored for seedling survival. As seen from Figure 6, more than half of the seedlings (56\%) died and 44\% survived for 60 days.

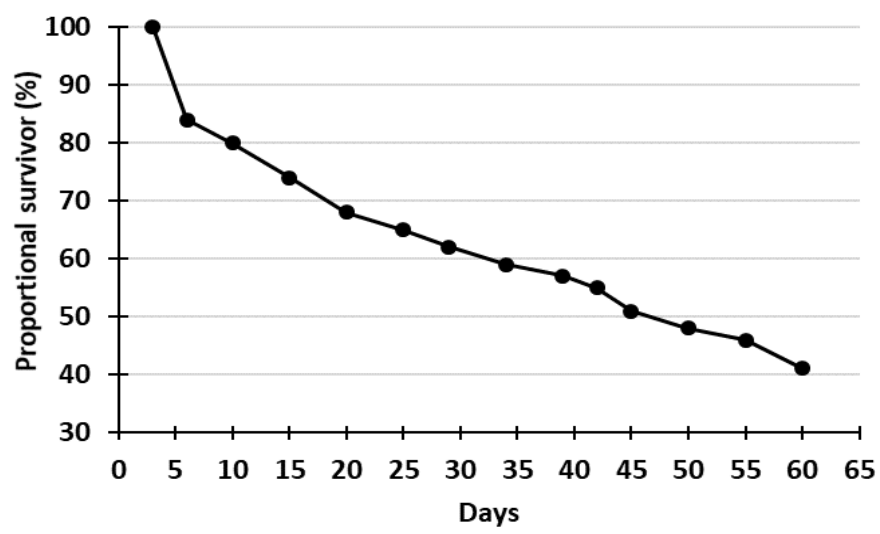

Figure 6. Proportional survival of Pinus nigra subsp. pallasiana var. yaltirikiana seedlings

The number of cotyledons was 8.3 (6-10). Likewise, Kaya and Temerit (1994) stated that the average number of cotyledons for 7 black pine populations they collected from Central Anatolia was 8.25.

In this study, the chromosome number of Pinus nigra subsp. pallasiana var. yaltirikiana was determined as $2 \mathrm{n}=24$, as known for black pines (Kaya et al., 1985; Salajova and Salaj, 1992; Hizume et al., 2002; Naydenov et al., 2003).

Ensuring the continuity of the limited number individuals of Pinus nigra subsp. pallasiana var. yaltirikiana in the natural distribution area is important in terms of genetic diversity and sustainability. These individuals should be taken under conservation by in-situ and ex-situ conservation strategies. As it is determined that seeds with the capacity to produce sound seeds and capability of germination can be obtained through current Pinus nigra subsp. pallasiana var. yaltirikiana individuals in the area, seedlings to be grown in the nursery by seeds with these characteristics can be planted around existing individuals to increase the number of theirs in this area.

In addition, seed orchard can be established in a different area by taking grafts from existing individuals, and sound seeds with the capability of germination can be obtained from these individuals. On the other hand, on the long run, observation must be performed in terms of purity of these seeds against the possibility of fertilizing female flowers of Pinus nigra subsp. pallasiana var. yaltirikiana individuals of the pollens of Pinus nigra subsp. pallasiana var. pallasiana individuals located in the same spread area.

\section{Conclusions and Suggestions}

Pinus nigra subsp. pallasiana var. yaltirikiana is an endemic variety in Turkey. The chromosome numbers of this taxon was found to be as $2 n=24$. Its pollen dimensions were measured and the result showed that pollen seemed healthy with good shape. Therefore, we can conclude that there is nothing wrong with the pollens for reproduction of Pinus nigra subsp. pallasiana var. yaltirikiana. On the other hand, it 
seemed that this plant taxon has poor cone, germinable seed production with poor seedling survival. Because $49 \%$ of the seeds were sound, and $71 \%$ of them germinated within $28^{\text {th }}$ days. Additionally, only $44 \%$ of seedlings survived and more than half of the seedlings $(56 \%)$ died within 60 days. These meant that seedling survival of this taxon under nursery conditions was poor. Sound seed production and their germination percentage were lower compared to the results of previous studies. These findings can be considered as an indicator of poor reproduction of Pinus nigra subsp. pallasiana var. yaltirikiana. As it has a limited distribution, it is possible that this taxon which is in danger of survival in the near future, can be removed successfully from the list of danger categories in the future with the protection of the habitat and protection efforts for population growth. Some additional studies are needed for better understanding for seedling survival and growth under field conditions in the second step. It is necessary to maintain the existing stand of this tree firstly to ensure the sustainability of the taxon; and then to increase the presence in the natural distribution area with the individuals to be grown from the seeds.

Acknowledgments. I would like to thank Assoc.Prof.Dr. Ilker Genc for his help in determination of chromosome number; Mr. Mustafa Diktas (Manager) and Mr. Fatih Sahin (Chief) from Sinop-Boyabat Forest Enterprice for their help in field studies.

\section{REFERENCES}

[1] Akalp, T. (2016): Statistical Methods. - Istanbul University Publication, IU number: 5219, Faculty of Forestry number: 511, Istanbul: 95-119. (in Turkish).

[2] Akkemik, U., Yılmaz, H., Oral, D., Kaya, A. (2011): Some Changes in Taxonomy of Pines (Pinus L.) Native to Turkey. - Forestist (JFFIU) 61(1): 63-78.

[3] Alptekin, U. (1987): Geographical Variations of Anatolian Black Pine (Pinus nigra Arn. subsp. pallasiana (Lamb.) Holmboe). - Forestist (JFFIU) Seri A 36(2): 132-154. (in Turkish).

[4] Altınordu, F., Martin, E., Hamzaoğlu, E., Çetin, Ö. (2014): New chromosome counts, karyotype analyses and asymmetry indices in some taxa of genus Senecio L. and related genera Tephroseris (Rchb.) Rchb. and Turanecio Hamzaoğlu belong to tribe Senecioneae (Asteraceae) from Turkey. - Plant Systematics and Evolution 300(10): 2205-2216. doi: 10.1007/s00606-014-1042-8.

[5] Atay, İ. (1959): Researches on Seed of Black Pine. - Forestist (JFFIU) A series 9(1): 4896. (in Turkish).

[6] Aytug, B. (1960): Quelques Mensurations des pollens de Pinus silvestris L. - Pollen et Spores, Paris 2(2): 305-309.

[7] Aytug, B. (1967): Pollen Morphology and Palynological Investigations on Important Gymnospermae Taxa of Turkey. - Kutulmuş Press, Istanbul. (in Turkish and French).

[8] Boydak, M., Calıskan, S. (2014): "Germination rate". - In Afforestation. OGEM-VAK, 978-975-93943-8-7, Istanbul, p.118. (in Turkish).

[9] Climate-Data.org (2019): https://tr.climate-data.org/asya/tuerkiye/sinop/boyabat-19451/. - accessed on 1 February 2019.

[10] Coode, J. E., Cullen, J. (1965): Pinus L. - In: Davis, P. H. (ed.) Flora of Turkey and East Aegean Islands. Edinburgh Univ. Press, Edinburgh 1: 72-75.

[11] Ekim, T., Koyuncu, M., Vural, M., Duman, H., Aytaç, Z., Adıgüzel, N. (eds.) (2000): Turkey Plants Red Data Book (Pteridophyta ve Spermatophyta). - TTKD ve Van 100. Y11 University Publication, Ankara, p. 9. (in Turkish). 
[12] GDF (General Directory of Forestry) (2011): Forest Management Plan for period of 2012-2020. - Kastamonu Regional Directory of Forestry, Boyabat Forest Enterprice, Turkey.

[13] Genc, M. (2004): Basic Principles of Silviculture. - Suleyman Demirel University, Forest Faculty, Publication number: 44, Isparta, p.233. (in Turkish).

[14] Hizume, M., Shibata, F., Matsusaki, Y., Garajova, Z. (2002): Chromosome identification and comparative karyotypic analyses of four Pinus species. - Theor Appl Genet 105: 491-497. doi: 10.1007/s00122-002-0975-4, accessed on 3 January 2019.

[15] Kandemir, A., Matarac1, T. (2018): Pinus L. - In: Güner, A., Kandemir, A., Menemen, Y., Yıldırım, H., Aslan, S., Ekşi, G., Güner, I., Çimen, A. Ö. (eds.) Illustrated Flora of Turkey. ANG Vakfı Nezahat Gökyiğit Botanik Bahçesi Yayınları. Istanbul, 2: 324-354. (in Turkish).

[16] Kaya, Z., Ching, K. K., Stafford, S. G. (1985): A Statistical Analysis of Karyotypes of European Black Pine (Pinus nigra Arnold) from Different Sources. - Silvae Genetica 34(4/5): 148-156.

[17] Kaya, Z., Temerit, A. (1994): Genetic Structure of Marginally Located Pinus nigra var. pallasiana Populations in Central Turkey. - Silvae Genetica 43(5/6): 272-277.

[18] Naydenov, K., Tremblay, F., Ganchev, P. (2003): Karyotypic Diversity in European Black Pine (Pinus nigra Arn.) from Bulgarian Provenances. - Phyton (Horn, Austria) 43(1): 9-28.

[19] Oral, D., Matarac1, T. (2018): A research on the presence of Pinus nigra J.F.Arnold subsp. pallasiana (Lamb.) Holmboe var. yaltirikiana Alptekin (Pinaceae) in Anatolia. Bağbahçe Bilim Dergisi 5(3): 10-16. doi: 10.30796/ANGV.2018.9, accessed on 3 January 2019.

[20] Salajova, T., Salaj, J. (1992): Somatic embryogenesis in European black pine (Pinus nigra Arn). - Biologia Plantarum 34(3-4): 213-218.

[21] Wodehouse, R. P. (1959): Pollen Grains, Their Structure, Identification and Significance. - Science and Medicine, New York.

[22] Yaltırı, F. (1988): Dendrology Course Book I, Gymnospermae. - Istanbul Univ. Faculty of Forestry Publications 3443/386, İstanbul. (in Turkish).

[23] Yaman, B., Sarıbas, M. (1999): Pollen Morphology of Varieties of Pinus nigra subsp pallasiana Growing Naturally in Turkey. - Symposium Proceedings Book, $1^{\text {st }}$ International Symposium on Protection of Natural Environment and Ehrami Karaçam, Kütahya, Turkey, 23-25 ${ }^{\text {th }}$ September 1999, 323-331. 